\title{
THE REPERCUSSION OF GRAMMATICAL AND CULTURAL CULPABILITY OF THE HOLY QUR'AN TRANSLATION TO RELIGIOUS HARMONY IN INDONESIA
}

\author{
Abdul Muta'ali \\ University of Indonesia - Indonesia | moetaalingua@gmail.com
}

\begin{abstract}
Arguably, among the sources of Islamic radicalization in Indonesia is the interpretation of certain terminology in the holy Qur'an. In a relatively long period, religious understanding of Indonesian society is shaped by the official Translation of the Holy Qur'an by Ministry of Religious Affairs. However, this translation contains several mistakes, including mistakes in translating key terms relating to the issue of warfare, non-Muslims and killing. This eventually contributes to radicalization of some element of Muslim society in Indonesia. The purpose of this research is to analyze error translation of The Holy Qur'an verses. Content analysis theory is applied in this research with grammatical and cultural approach against the Holy Qur'an translation by Ministry of Religious Affairs of Indonesia (MORA). The research shows that 90 fatal errors in translation of The Holy Qur'an verses regarding infidels and polytheists are confirmed. The errors might be play role in the increasing religious disharmony in Indonesia. Furthermore, they arguably have fueled Islambased terrorism acts.
\end{abstract}

Keywords: Qur'an translation, polytheist, infidel, MoRA.

\section{Introduction}

There are many explanations behind Islamic radicalization trend in Indonesia. Among the chief explanation is the interpretation issue of the sacred scripts; the Holy Qur'an and the Prophet sayings (hadith). for Muslims, the two sacred texts are fundamental in guiding their lives. However, since the texts are in Arabic, for those who do not master Arabic language, things get complicated. Several Indonesian 
traditional Muslims rely upon the interpretation provided by the ulama (religious clerics) of various leanings and persuasion, while others, especially the modern Muslims, go to the translation of the two scripts. Both ways have own limitations. However, a number of terrorism acts and religious radicalization had been taken place, directly or indirectly, as a result of scriptural understanding, especially on Qur'anic texts that speak about warfare. This article aims to show that the Qur'an does not advocate unjust war. It is the translation that justifies this act of terrors. On the other words, it is the inaccuracy of translation, which sourced from lack of knowledge of sufficient Arabic language, that impacts to various kinds of terrorism acts.

In a seminar held by of National Agency for Combating Terrorism on 11th May 2011 at Al-Hikam Boarding School Depok, West Java, the chief of the agency states that Indonesian terrorism acts within 10 years are absolutely alarming since it was built on religious understanding which is spread among youth who "falls in love with religion". That is to say, this young generation studies religion instantly and less comprehensive. ${ }^{1}$ Usually, this youth circles study the religion through some translated books or religious websites contain certain lessons without elaborating deep knowledge in understanding religious texts. Since the majority of religious texts written in Arabic, the translation becomes main vehicle. If the translation is problematic in some ways, the meaning will be altered or changed. This, in turn, will lead into wrong or inaccurate interpretation.

Generally, when the Holy Qur'an is concerned, Indonesian society especially the youth study the Holy Qur'an through the translation version from Ministry of Religious Affairs. In a relatively long period, the interpretation of the Holy Qur'an of Indonesian Muslims is shaped by the Qur'an translation from Ministry of Religious Affairs. If there is an inaccurate translation, the consequence is grave to their understanding of the text. Here is a very obvious example, in the Holy Qur'an Translation from Ministry of Religious Affairs, every single verse stated Qätil al-Mushrikina is always translated as "kill the polytheists". Whenever the object is polytheist or infidel it must translated as "to kill!," Whereas morphological derivative pattern of qâtil derived from qâtala- yuqātilu, which has meaning as "to wage war".

1 Ansyad Mbai, NII Movement; Cause and Its Solution (Paper conveyed at National Seminar, Al-Hikam Boarding School Depok, 11 May 2011). 
In Arabic, this verb segmented as verb pattern III which has reciprocal meaning. Kill and war are vastly different. Will "to kill" has individual meaning, tribal, and primitive, "to wage war" with each other is more egalitarian since it is in the authority of the state or leadership of a given community. There is mechanism to wage war, who must be fought against, and who has right to wage war instruction. Therefore, "to kill" is one-way command while "to wage war" has reciprocal meaning and it is two ways communication between two parties. In fact, there are a number of errors translations on that literature, especially several verses about polytheists. If this culpability is ignored, certain Muslims would believe it and use it as religious justifications for violence and terror against non-Muslims. The word (1) qatala-yuqätilu is repeated 166 times in The Holy Qur'an and wrongly translated 90 times.

This article unfolds upon this background. Questions on this article are formulated into these two things: How far is the impact of culpability of interpretation, which happens in the translation of the Holy Qur'an by Indonesia Ministry of Religious Affairs, to warfare verses and religious harmony? And what is the concept of religious text translation?

Admittedly, research about culpability of the Holy Qur'an Translation by Ministry of Religious Affairs is not the first one. Muhammad Thalib writes Corrections to the Holy Qur'an Harfiyyab Translation by Ministry of Religious Affairs that published by Mujahidin Assembly on 2012. ${ }^{2}$ On that book, Muhammad Thalib mentioned 17 verses from 3229 wrong interpretation verses. However, he serves the mission of his radical group, the Mujahideen Assembly. Consequently, his book contains heavy bias. In contrast, focus on this article is the verses in the Holy Qur'an which are estimated as wrongly interpreted based on the grammatical and cultural interpretation which is the basis of translation theory.

\section{Translation in Theory}

The basic of translation analysis is text. Therefore, discourse analysis like Halliday and Hassan in Cohesion in English, Emily Apter in Translation with No Original; Scandals of Textual Reproduction are also used

\footnotetext{
2 Muhammad Thalib, The Holy Qur'an Translation Correction Ministry of Religious Affairs; Aqidah Review, Sharia, Muamala, Iqtishadia (Yogyakarta: An-Nabawy Institution, 2011), pp. 34-132.
} 
in order to analyze the text. Halliday and Hasan claimed that text is any passage, verbal or non-verbal, as long as created one idea. The interesting part is the differentiation between text and non-text based on public opinion. In their view, text is a structural sentences showed relations between them while non-text is sentences without unity. ${ }^{3}$ Then, Halliday and Hassan added some clues about text. First of all, text has texture since language is absolutely showed totality of its meaning. Secondly, text has relation marked by cohesive elements. Last but not least, meaning relation within text can be found semantically. In translated text, text often separated as two big groups, general text and special text. ${ }^{4}$ The text of the Holy Qur'an is clearly special text, the meaning and purpose on it are also special. Therefore, it also needs special understanding. Minor culpability interpretation created special wrong understanding which has grave effects.

Qualitative method is applied on this research with content analysis approach using grammatical and cultural against the Holy Qur'an verses. The main reference of this research is the Holy Qur'an Translation published by Ministry of Religious Affairs of the Republic of Indonesia. Procedural steps in this research are as follow. Firstly, collected and inventoried the translation of The Holy Qur'an published by Ministry of Religious Affairs of the Republic of Indonesia.

\section{MORA and the Translation of Holy Qur'an}

In Indonesia, there are many versions of the translation of the Holy Qur'an, namely; the Holy Qur'an translation by Dr. Mahmud Junus ${ }^{5}$, translation by HB. Jassin ${ }^{6}$, translation of the Holy Qur'an into Javanese by Bishri Musthofa, ${ }^{7}$ etc. The Ministry of Religious Affairs

\footnotetext{
${ }^{3}$ Halliday and Hasan, Cohesian in English (London: Longman, 1976), p. 29.

${ }^{4}$ Rahayu Hidayat, Synthetic Text; in Education and Functional First Stage Translator Training (Jakarta: Ministry of the State Secretariat of the Republic of Indonesia, Jakarta, 2012), p. 21

${ }^{5}$ Khadher Ahmad and Khairuddin Mawardi, "Contribution of Mahmud Yunus To the Interpretation of the Qur'an: A study of Tafsir Qur'an Karim," Research in Islamic Studies, 1, 1 (2014): pp. 88-101

6 Yusuf Rahman, "The Controversy around HB. Jassin: a Study of His al-Qur'anul Karim Bacaan Mulia and al-Qur'an al-Karim Berwajah Puisi," in Abdullah Saeed (ed.), Approaches to The Quran in Contemporary Indonesia, pp. 85-106,

${ }^{7}$ Islah Gusmian, "Bahasa dan AKsara Tafsir Al-Qur'an di Indonesia: dari Tradisi, Hierarki Hingga Kepentingan Pembaca,” Tsaqafah, 6, 1 (2010), pp. 1-26
} 
with its Agency of the Holy Qur'an Supervision and Correction, has the role in supervising the translations of the Holy Qur'an that circulate in Indonesia. The translation of the Ministry itself was firstly published in 1971. It was translated by a team consisting of several experts of Islam and Arabic literature. Since then, there was virtually no update and language review. Because of its position as state initiative, its translation of the Holy Qur'an is widely referred by Muslim community in Indonesia. Moreover, other printing companies also use this translation version and sell the translation to the public because those companies are allowed to use the translation virtually without paying any fee to the ministry. Therefore, it has a strategic role in shaping the understanding of Muslims in Indonesia, who in majority do not understand Arabic, in understanding this divine message. When there is inaccurate translation, the impact is potentially Indonesian wide.

This article focuses on the grammatical and cultural culpability of the translation, especially in the second chapter of (al-Baqarah, lit. the Cow) of the Holy Qur'an which relate to the terms of killing and warfare. This Al-Baqarah chapter consists of 286 verses, which is the longest chapter in the Holy Qur'an, talked about 3 things; three segmentation of people in facing The Holy Qur'an, oneness and God Power, as well as God warning to the Children of Israel. There are seven verses that contain inaccurate grammatical and cultural interpretation, namely verse 28, 41, 91, 120, 130, 132, and 191 .

\section{Verse 28}

Text of this verse is: Kaifa takfurüna billāh wa kuntum amwatan fa abyäkum, thumma yumitukum thumma yubyikum thumma ilaibi turja'ü. MoRA translation: "Why do you infidel to Allah, whereas you were dead and Allah gave you life then take your life".

Wrong interpretation occurred in the translation of takfuruna billāh it translated as "infidel". In Arabic Linguistic word infidel is an isim fa' ${ }^{-} i l$ or active participle. Whereas takfuruna billäh is an imperfective or fi íl mudari: In translation theory, although translation means forwarding message process, it is better for translator to use the same morphological form as long as they can use it with the same message content. Then, takfurüna billāh is more accurate translated as "you

\footnotetext{
${ }^{8}$ See The MORA Translation to the Holy Qur'an, 13.
} 
refuse the favors of Allah". Strong reason of word 'ka-fa-ra' translation as "to refuse" is verse 85 of the same chapter of Al-Baqarah. The verse of "....afatu'minübi ba'di al-kitābi wa takfuruna bi ba'd is translated into: "Do you believe in some scripture and do not in others scripture?" In this case the The Holy Qur'an translation is correct. Why verse 85 translated as "to refuse" but verse 28 translates as "to be infidel" provided that they are in the same context. Actually, the verse 85 talks about proofs of Allah Power, not in a warfare context.

Culturally, Arabs commonly use the word "takfuru" (you refuse or lie) or "kafarta" (you lied) in the context of social science. For instance, "kafarta hubbi" (you lied to my love). However, if the use of the word "ka-fa-ra" is translated literally in Indonesian, the message is very much mistaken. Because the word "Kafir" in Indonesian is the opposite of the word 'mukmin'. while "kafir" means infidel, the "mukmin" means believers. The case is different with verse 34 in the same letter that is correctly translated. The use of the word 'kafir' in this paragraph is correct. "Illa iblisa abā wastakbara wa kàna min al-käfirin". Translation of Ministry of Religious Affairs is: "unless the devil, he was reluctant and arrogant and he belonged to the people who disbelieve". ${ }^{10}$

\section{Verse 41 and verse 91}

The text of the verse 41 is: wa àminù bimā anzaltu musaddiqal limā ma'akum wala takūin awwala káfirin bih. The translation of MORA is: "And ye have faith in what I have sent down (the Qur'an) that confirms what you have (Torab), and do not be the first person who disbelieves him". ${ }^{11}$ The text of the verse 91 is: "wa idhā qìla labum àminū bimā anzalallāhu qālu nu'minu bimà unzila 'alaina wa yakfuruna bimā wara'ab". The translation by MORA version is: "When it is said to them," believe in the Qur'an Allab has revealed, "they say", we just believe in what was revealed to us and they disbelieve in alQur'an that was revealed after that". ${ }^{12}$

In these 2 (two) verses, the word 'käfir' is using morphological form of ism fa'il or perpetrator. So, at first glance it seems like a correct translation above religious ministry, "the first infidel". However, as

\footnotetext{
${ }^{9}$ Ibid., p. 24.

${ }^{10}$ Ibid., p. 14

11 Ibid., p. 15.

12 Ibid., pp. 25-26.
} 
shown by Mutawalli Sha'rawi in the context of his commentary ${ }^{13}$ on the verse of the Qur'an, there is actually implicitly process and stages of disbelief categorization interaction or community groups to particular holy book the Quran. The first stage, there are already people who are reading and believing but they do not practice. In the ideology of Islamic monotheism or type is called fasiq. The second stage, there are people who have read the Quran, but hesitated, called munafiq (hypocrites). The third stage, there are people who have already read but do not believe, called Abl al-Kitab. But it is not an initial disclaim enmity with Muslims. The fourth stage, since the Qur'an is the physical form of text, when text is presented, there is the attitude of some groups who do not want to read but still respect Islam, called Abl al-Kitab. While there is a fifth stage of people that did not want to read the Qur'an, but they refuse in Islam called kafir. In the context of this MORA translation, it seems to immediately jump to the fifth stage and ignore the stages one to four. Thus, it is advisable to propose a revised translation by taking the average of the meaning from the context of the verse. This is the offer "And do not you be the first person to refuse to Al-Quran".

\section{Verse 120}

This verse of the text: "wa lan tarda 'anka al-yabüdu wala an-nasāara ḅattā tattabi'a millatabum. Qul inna budallāhi huwa al-budā. Wa la inittaba'ta abwā ahum ba 'da al-ladrí jā'aka min al-'ilmi mà laka minallāhi walìin wa là nasiir". That is the Indonesian version of the Ministry of religion "The Jews and Christians will not be pleased to you until you follow their religion. Say: 'Verily, Allah's guidance is the only guidance (which is true)'. And if you follow their desires after the knowledge came into you, God is no longer the protector nor belper for you'. ${ }^{14}$

Errors of translation in this verse occurs in the translation of the sentence lan tarda 'anka al-yahüdu wala an-nașära translated "the Jews and the Christians will not be pleased". In this verse, the word $l a$ and lan both translated with "will not". Though the two different meanings. "lan" means "will not" (never), while the "la" means "no" (no). If translated one by one supposedly "Jews will never be pleased" and "those Christians cannot be happy". It can be understood that "lan"

\footnotetext{
${ }^{13}$ Mutawalli Sya'rawi, Tafsir Sya'rawi (Beirut: n.p., n.d.), p. 69.

${ }^{14}$ Ibid., p. 32.
} 
and "ld" translates the same as "will not" because of the presence of "waw" (and) as connecting particles. So, as to facilitate the readers likened translation as "the Jews and the Christians will not be pleased". In Arabic semantic grammar, this leads to the understanding of Indonesian Muslim society that Jews and Christians are alike in a sense that both people will never please until Muslims follow their religion. However, that should not be the case if the verse translated correctly. While the verse has state clearly that Jews will never please until Muslim follow their religion, the verse does not rule out the possibility of Muslim-Christian harmony. The translation, therefore, should be: "the Jews different from Christians can, they want you to follow the teachings".

\section{Verse 130}

The text of this verse sounds: "wa man yarghabu 'an millati ibräbima illa man safiba nafsabu. Wa laqad iștafaināhu fi al-dunya, wa innabū fi alakkirati lamina as-salibihin". Translation of MORA is: "And no one hates the religion of Ibrabim except someone who make a fool of himself, and indeed we have chosen bim in this world and in the hereafter he actually includes those pious". ${ }^{15}$

Translation mistakes in this paragraph contained in the translation of the word 'safiba nafsah' which is translated into 'make a fool of himself. In the dictionary $\mathrm{Al}$ - Mu' jam Al-Qasith, the word 'sa-fi-ha' means not productive or useless. ${ }^{16}$ In Arabic there are several levels of the meaning of words that has a field 'dumb', the lowest so-called 'safih', then 'balid', and the highest level of dumb commonly referred to as 'jahil'. ${ }^{17}$ 'Safih' is commonly interpreted to be useless. 'Balid' is usually translated with lazy thinking, and 'ignorant' is translated by fools. Thus the translation version of MORA has occurred immediately leap to interpret 'safih' using the third level. Of course this will make the significant leap to justify stigma that people who do not necessarily believe in the doctrine of monotheism soon would be stamped. Though faith is a belief is a long process that takes a long time anyway. Someone should read first, consult with religious leaders in the faith and instill a confidence. So if we directly refer to someone who does not believe in the doctrine or ideology that we believe to be a fool, even though we both are looking for.

\footnotetext{
15 Ibid., p. 34.

${ }^{16}$ Syauqi Dhaif et.al, Al-Mu'jam Al-Wasith (Cairo: Dar El-Arab, 1972), p. 458.

17 Ahmad Khalil Farahidi, Mu'jam Al-'Ain, volume 7 (Beirut: Dar El-Fikri, 2000), p. 139.
} 


\section{Verse 132}

The text of this verse reads: "wa wașa bibā ibrähimu banībi wa ya qūbu

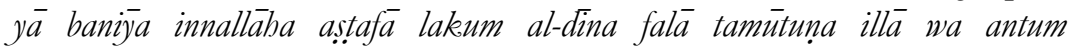
muslimun". the translation of MORA is: "And Ibrabim had willed it to his children, as did Jacob. (He said): 'O my sons! Indeed, Allah has chosen this religion for you, so do not die except in embracing Islam". ${ }^{18}$

The context of Ibrahim's monotheism religion that becomes the parent of all divine religions, yet in the context of the definition of religion that we know today is Judaism, Christianity, and Islam. Understanding this paragraph must be integrated with an understanding of the previous verse, namely verse 131 the same chapter which reads: "Idh qāla lahü rabbubū aslim, qāla aslamtu li rabbi al'alamin". Defined in the translations by MORA: "When his Lord said to him: "Obey and comply!" Ibrahim replied: "I have surrendered to the Lord of the universe". Because of this, it can clearly be seen that translation of verse 132 as "so do not die except embracing Islam" is not consistent. Why are pieces of verse 132 "muslimun" is defined "to embrace Islam" (becoming Muslim) while verse 131 pieces the word "aslim" and "aslamtu" is simply translated as "submission"?, Even though both are derived from the same root and the same discourse context as well. This is similar to the translation of verse 64 of Ali Imran letter, "fa qülu al-ashbadu bi annā muslimun", which is translated by MORA to "bear witness, that we are the ones who have surrendered (to Allab)". The part of the sentence, "anna muslimün", not translated to: "we are Muslims".

Translation of verse 132 "so do not die except in embracing Islam", in fact is also contrary to the Qur'an itself is verse 256 of Surah alBaqarah, which reads: "Laa ikrāha fiddin" (meaning: "there is no compulsion to enter the religion of Islam"). ${ }^{19}$ In the part of verse 132 translation, the translation inconsistencies of Chapter al-Baqarah are also seen if we compare it with the translation of the same verse 136 that read: "...là nufarriqu baina ạ̣adin minbum wa nạ̣nu labü muslimūn", which is translated into "...we make no distinction between any of them and we submit to Him". At verse 132 "Muslimun" means "embrace Islam", while at verse 136 "Muslimun" means "submission".

18 See Ibid., p. 34.

${ }^{19}$ MORA Translation, p. 63. 
Similar to translation by MORA, Errors of interpretation is found in The Holy Qur'an: Tafsiriyyah Translation issued by Majelis Mujahidin Indonesia (MMI). Verses 131-132 of this chapter Al Baqarah translated by MMI with "O Quraysh, remember when God of Ibrahim said to him: "O Ibrahim, you are immediately converted to Islam without any hesitation". He said, "I embraced Islam sincerely for Allah, the Supreme Organize and Master of the Universe" (Surah alBaqarah: 131). Ibrahim and Ya'qub were instructing his sons. Ibrahim said: "O my dear sons, truly God had chosen Islam as your religion. Therefore you do not ever die, unless you die as Muslims".

\section{Verse 191}

The text of this verse is: "waqtulūbum haithu thaqiftumūbum wa akbrijübum min haithu akbrajükum wa al-fitnatu ashaddu min al-qatli, wa là

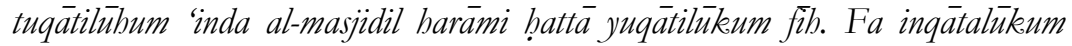
faqtulübum. Kadzàlika jazà'u al-kâfirin". Translation of MORA is: "And slay them wherever you find them, and drive them out from their place like they drove you out (from Mecca); and slander has a greater danger than assassination, and do not fight them in the Mosque of Haram, except if they fight you in that place. If they fight you (in it), then kill them. Such is the reward of disbelievers". ${ }^{20}$

Errors of translation in this verse occurs in part of verse "waqtulübum haithu thaqiftumübum", which is translated into "and slay them wherever you find them". More specifically there is an error in the interpretation of part of the verse 'thaqiftumübum' which is defined as "wherever you find them". Explicit understanding of this verse is gruesome and dangerous. Just look at "and slay them wherever you find them". Anyone who are discovered to have non-Muslim identity, he or she should be killed.

In Arabic grammar, the word 'thaqiftumühum', derived from the root word 'tsa-qa-fa'. In some classical dictionaries like $\mathrm{Mu}$ 'jam al"Ain ${ }^{21}$ and Lisan al-'Arab, ${ }^{22}$ interpreted by as "to attack" and "to make slanderous act". Thus, there appears to be missing from the translation meaning 'thaqiftumühum' contained in the Qur'an translation of MORA. Thus, the more appropriate interpretation should be: "and kill them wherever you find them and make slanderous attack".

\footnotetext{
${ }^{20}$ Ibid., p. 46

21 Al-Farahidi, Mu'jam Al-'Ain, p. 120.

${ }^{22}$ See Louis Ma'luf, al-Munjid (Beirut: Dar al-Fikr, 2002), p. 319.
} 


\section{Conclusion}

Grammatical errors and cultural interpretations of the Qur'an Translations by MORA happen because it only took a partial translation of one of the meanings contained in words. It has ignored that the Holy Qur'an contains elements of all polysemy-related words. It is also inconsistent in translating words with identical roots across the verses. In the focus of the article is the second (and the largest) chapter of the Holy Quran, al-Baqarah, it has been noted several errors in translation. The errors also take place in words relating to the definition of Islam, the issue of non-Muslims, and the gradation of infidelity. The consequence or this inaccuracy is grave since the translation has put non-Muslim as enemy and put Islam as the sole truth in Abrahamic religions. Arguably, radical approaches to Islam which manifest in Indonesia recent years in form of unpleasant attitude towards non-Muslims and terror attacks may result of reading of this translation. []

\section{References}

\section{Books and Articles}

Abdul Baqi, Muhammad Fuad. Mu'jam Mufahras li Al-Faą̧il Qur'anil karim. Beirut: Dar El-Jail, 1988.

Ahmad, Khadher Ahmad and Khairuddin Mawardi. "Contribution of Mahmud Yunus To the Interpretation of the Qur'an: A study of Tafsir Qur'an Karim.” Research in Islamic Studies, 1, 1 (2014): pp. 88-101

Allen, Matthew. Smart Tbinking: Skills for Critical Understanding and Writing. Oxford: Oxford University Press, 1997.

Dickin, James. Thinking Arabic Translation. New York: Routledge, 2002.

Farahidi, Ahmad Khalil. Mu'jamul Ain. Cairo: Dar El-Arabi, 1997.

Gusmian, Islah. "Bahasa dan Aksara Tafsir Al-Qur'an di Indonesia: dari Tradisi, Hierarki Hingga Kepentingan Pembaca." Tsaqafah, 6, 1 (2010): pp. 1-26

Halliday, M.A.K \& Ruqaiya Hasan. Cohesion in English. London: Longman, 1976.

Hasan, Tammam. Rawa'i 'ul bayan fi al-Qur'an al-Karim. Cairo: 'Alam alKutub Publising, 1997. 
Muta'ali, Abdul. Kontribusi Bahasa Arab dalam kosakata Babasa Indonesia. Purwakarta: Nur Elsyam Publishing, 2010.

---------. Membangun Negara Kuat: Kontribusi Islam terbadap Pemikiran Politik Barat. Jakarta: UI Press, 2013.

Rahman, Yusuf. Rahman. "The Controversy around HB. Jassin: a Study of His al-Qur'anul Karim Bacaan Mulia and al-Qur'an alKarim berwajah Puisi." Abdullah Saeed (ed.). Approaches to The Quran in Contemporary Indonesia. Oxford: Oxford University Press in association with The Institute of Ismaili Studies, 2005.

Thalib, Muhammad. Koreksi Tarjamah Harfiyah Al-Qur'an Kemenag RI: Tinjauan Aqidah, Syari'ah, Mu'amalah, Iqtishadiyah. Yogyakarta: Ma'had An-Nabawy, 2011. 